\title{
Organizational Culture and Its Relationship with Employee Stress, Enjoyment of Work and Productivity
}

\author{
Janna Olynick ${ }^{1,2} \&$ Han Z. Li $^{1}$ \\ ${ }^{1}$ Psychology Department, University of Northern British Columbia, Prince George, Canada \\ ${ }^{2}$ Northern Health Authority, Prince George, Canada \\ Correspondence: Han Li, Psychology Department, University of Northern British Columbia, Prince George, BC., \\ V2N 4Z9, Canada. E-mail: lih@unbc.ca
}

Received: April 12, 2020

Accepted: May 8, 2020

Online Published: May 12, 2020

doi:10.5539/ijps.v12n2p14

URL: https://doi.org/10.5539/ijps.v12n2p14

\begin{abstract}
Despite a recent resurgence in the study of organizational culture, insufficient attention has been paid to the impact of the types of organizational culture on employee well-being and productivity in Canadian settings. This study investigated which types of organizational culture are most closely related to employee levels of work-related stress, enjoyment of work and self-perceived productivity. A secondary research interest was to identify the dominant culture type at the studied university in northern Canada. A total of 193 staff members from various departments (e.g., academic services, facilities, student life) completed an online survey containing questions on organizational culture, stress, enjoyment of work and productivity. Three intriguing findings were generated from the data: (1) All four types of organizational culture - clan, hierarchy, adhocracy, market - were identified at the institution; (2) the hierarchy culture was most prevalent, followed by the adhocracy culture, the market culture and then the clan culture; and (3) the type of organizational culture was significantly related to stress, enjoyment of work and productivity. Employees working in a clan culture reported the lowest levels of stress, and highest levels of enjoyment and productivity, followed by those in the adhocracy and hierarchy cultures, lastly the market culture. Important implications include: (1) Organizational leaders need to take into account the role organizational culture plays in employee well-being and workplace functioning, and (2) Organizational leaders should implement strategies to create a workplace culture that promotes employee well-being and productivity.
\end{abstract}

Keywords: organizational culture, workplace stress, productivity, enjoyment of work

\section{Introduction}

\subsection{The Complex History of Organizational Culture}

Organizational culture is a phenomenon that has been studied for many a decade, with research tracing back to the 1960s (Kaczka \& Kirk, 1968; Litwin \& Stringer, 1968). Early studies have identified organizational culture as a component of organizational success (Cameron \& Quinn, 2005; Denison, 1996), yet it was not until later years that the nature of this relationship garnered interest and exploration. Even though studies have been conducted on the relationship between organizational culture and employee experiences, such studies seldom examine specific types of organizational culture (OCAI Online, 2012). Furthermore, few studies have been conducted in Canadian workplace settings. Thus it is of great urgency to conduct such a study in Canada.

To effectively address this issue, it is imperative that organizational culture be better understood. Knowledge gained from research focused on this problem is crucial for addressing an evident paucity in knowledge, as well as providing recommendations that can be used by organizational leaders for quality improvement and employee retention.

\subsection{Background: What We Know about Organizational Culture and Employee Workplace Experience}

A work environment is defined as a multi-dimensional system, rooted in the beliefs, rules and values held by members of an organization. These shared values and ways of working form an organizational culture. Organizational culture is also influenced by factors such as management views, national culture and the industry of a corporation. Once formed, it is central to the success of an organization (Cameron \& Quinn, 2005; Denison, 1996; Goffee \& Jones, 1996; Lok \& Crawford, 2004) and the employee workplace experience (Schein, 1984). 
Studies show that an employee's perception of their work environment can greatly influence employee health, enjoyment and quality of work (Hellriegel \& Slocum, 1974).

Numerous types of organizational culture have been proposed, with Cameron and Quinn's competing values framework model being at the forefront. The competing values framework explains that there are four kinds of organizational culture which compete with one another. The parameters of this model include focus (internal versus external) and level of stability/control versus flexibility. Within this structure, there are four quadrants; each representing one type of organizational culture. First, the clan culture operates on cooperation and group morale, resembling a family. This culture takes employee loyalty and customer satisfaction into consideration. Second, the adhocracy culture is dynamic and emphasizes change, creativity, flexibility and employee individuality (Denison \& Spreitzer, 1991; Sherman et al., 2014). Third, the market culture is the most competitive of the four cultures, being results-based and focusing on goals and competition. Finally, the hierarchy culture is viewed as a formalized/structured, policy and procedure-governed environment, in which coordination between employees, stability, security, conformity and efficiency are emphasized (Denison \& Spreitzer, 1991; OCAI Online, 2012; Sherman et al., 2014).

\subsubsection{Organizational Culture and Stress}

Organizational culture plays a large role in the health of employees (Kane-Urrabanzo, 2006) and the well-being of a corporation, measured through employee illness, fatigue and absenteeism (Peterson \& Wilson, 2002). Studies have found that organizational norms, embedded in organizational culture, explain a substantial amount of job stress variance (Hammer, Bayazit, Saksvik, Nytro, \& Torvatn, 2004). Research shows that feelings of job stress are frequently associated with a lack of supervisor support, neglect of employee rights, feeling overloaded with work (Motowidlo, Manning, \& Packard, 1986), perceived job insecurity, low control over work (Sparks, Faragher, \& Cooper, 2001), extended work hours (Maslach \& Leiter, 1997; Rosa, Colligan, \& Lewis, 1989), workplace conflict (Hammer et al., 2004), and type A management style (competitive, ambitious, aggressive) (Ganster, Schaubroek, Sime, \& Mayes, 1990). Studies have found increases in employee absenteeism when at least one of the previously mentioned factors is present (Vahtera, Kivimaki, \& Pentii, 1997). Conversely, high scores on employee health and happiness are associated with an encouraging and positive work environment, one that emphasizes social connection among employees.

\subsubsection{Organizational Culture and Enjoyment of Work}

Organizational culture is related to employee job satisfaction, involvement, commitment and enjoyment of work (Lok \& Crawford, 2004; Sparks, Faragher, \& Cooper, 2001; Trice \& Beyer, 1993; Williams \& Hazer, 1986). There are specific characteristics of organizational culture that seem to influence overall enjoyment of and commitment to work (Cawsey, 1973; Friedlander \& Margulies, 1969; Kaczka \& Kirk, 1968; Litwin \& Stringer, 1968). When employees perceive a participative management style (emphasizing group cohesiveness, cooperative strategies and interpersonal relations), they tend to have higher levels of happiness and job satisfaction (Hellriegel \& Slocum, 1974; Soonhee, 2002). Moreover, an organization's physical environment, or workspace, is known to affect employee enjoyment of work (Earle, 2003). Organizational culture has been reported to influence job commitment, that is, an innovative, democratic and supportive organizational leadership style has positive effects on employee commitment, and it is also related to enjoyment (Lok \& Crawford, 2004). Furthermore, perceived control over one's work influences job commitment (Spector, 1986).

\subsubsection{Organizational Culture and Productivity}

Productivity has been deemed a major component of flourishing organizations and is easily influenced by organizational culture (Brown \& Leigh, 1996; Cawsey, 1973; Dunnette, 1973; Frederickson, 1966; Friedlander \& Greenberg, 1971; Kaczka \& Kirk, 1968; Kane-Urrabanzo, 2006; Sheridan, 1992). Although studies have indicated that working in a consistent and positive environment is related to more consistent performance records (Hellriegel \& Slocum, 1974), it is believed there are specific components of organizational culture that contribute to increased productivity (Clements-Croome, 2006). When the characteristics of trustworthiness, empowerment, consistency and mentorship are present in a workplace, employees tend to produce greater quality of work, and at a faster rate (Hellriegel \& Slocum, 1974; Kane-Urrabanzo, 2006). It has also been found that when employees hold positive views of their organization, and when organizational and personal goals align, employees tend to spend more time on work tasks and put more complete efforts into their job (Brown \& Leigh, 1996; Mathieu \& Zajac, 1990).

Researchers have suggested that increased involvement by management (Conger \& Kanungo, 1988; Malone, 1997), consistency and support by management (Hellriegel \& Slocum, 1974), and increased employee responsibility and motivation are all associated with greater productivity (Hackman \& Oldham, 1975). 
Conversely, factors such as ego-depletion (e.g., exhaustion of one's mental resources) and a non-democratic environment can decrease employee motivation, dedication and effort to work tasks, thereby reducing productivity (Baumeister, Bratslavsky, Muraven, \& Tice, 1998; Peterson \& Wilson, 2002).

\subsection{Introduction to the Present Study}

Although previous studies have found that aspects of organizational culture contribute to workplace productivity, employee health and enjoyment of work, the exact nature of the association between types of organizational culture and workplace experiences remains less explored. As such, the objective of the present study was to explore the nature of this association. A survey was used to gather the insights of staff members on both organizational culture and their workplace experiences. The purpose of this research was to assess the relationship of culture type with job stress, enjoyment of work and self-perceived productivity in a sample of staff members at a small northern university in Canada. This is one of the few studies examining specific type/s of organizational culture, and the link between types of organizational culture (clan, hierarchy, adhocracy and market) with employee stress, enjoyment and productivity. Four research questions were formed for this study:

1. What is the dominant type of organizational culture at the studied university?

2. Are there differences in levels of employee perceived stress across the four types of organizational culture?

3. Are there differences in levels of employee enjoyment of work across the four types of organizational culture?

4. Are there differences in levels of employee self-perceived productivity across the four types of organizational culture?

Specific hypotheses were not formed given the exploratory nature of the study.

\section{Method and Participants}

This study used an online survey with both close- and open-ended questions to explore the four research questions in a sample of staff members at a small university in Canada.

\subsection{Participant Characteristics}

A total of 227 participants responded to the online survey. However, due to incomplete responses, only data from 193 participants were analyzed. Participants were English-speaking staff members at the university, were either regular part-time or full-time employees, and had worked at the institution for a minimum of four months. Participants were employed in various sectors of work, including maintenance and facilities, administration, research, housing, finance, library services, registration, information technology services, retail, communications, health services, academic services, external relations and general management. A detailed display of participant characteristics is offered in Table 1 . 
Table 1. Participant characteristics: Frequencies on demographic variables

\begin{tabular}{|c|c|}
\hline Variable & Participants $n(\%)$ \\
\hline \multicolumn{2}{|l|}{ Age } \\
\hline Under 30 & $30(16.1)$ \\
\hline 30-39 & $51(27.4)$ \\
\hline $40-49$ & $60(32.3)$ \\
\hline $50-59$ & $40(21.5)$ \\
\hline $60+$ & $5(2.7)$ \\
\hline \multicolumn{2}{|l|}{ Gender } \\
\hline Male & $54(29.2)$ \\
\hline Female & $131(70.8)$ \\
\hline \multicolumn{2}{|c|}{ Years worked at university } \\
\hline 4 months-4 years & $84(45.4)$ \\
\hline $5-9$ years & 48 (25.9) \\
\hline $10-14$ years & $26(14.1)$ \\
\hline $15+$ years & $27(14.6)$ \\
\hline \multicolumn{2}{|l|}{ Overall health } \\
\hline Poor & * \\
\hline Fair & $20(10.5)$ \\
\hline Good & $115(60.2)$ \\
\hline Excellent & $54(28.3)$ \\
\hline \multicolumn{2}{|l|}{ Annual salary level } \\
\hline Under $\$ 30,000$ & $15(8.4)$ \\
\hline$\$ 30-39,999$ & $17(9.6)$ \\
\hline$\$ 40-49,999$ & $45(25.3)$ \\
\hline$\$ 50-59,999$ & $45(25.3)$ \\
\hline$\$ 60-69,999$ & $32(18.0)$ \\
\hline$\$ 70-79,999$ & $14(7.9)$ \\
\hline$\$ 80,000+$ & $10(5.6)$ \\
\hline
\end{tabular}

Note. $\mathrm{N}=193$

${ }^{*}$ Cell suppression given $\mathrm{n}<5$

\subsection{Procedure}

\subsubsection{Apparatus, Materials and Measures}

An online survey was used in this study, which consisted of 25 questions developed by the project researchers after conducting a thorough review of existing organizational culture survey questions and assessment instruments. The survey was constructed in a fashion that questions corresponded with one of the five topic areas: organizational culture, work-related stress, enjoyment of work, self-perceived productivity and demographics.

The majority of the survey questions followed a 5-point Likert scale, although there were also rank-order and multiple-choice questions which aided in calculating the perceived culture of the workplace. Sample questions included "Do you enjoy going to work?" and "Do you feel your work environment brings out your highest productivity?". To determine the type of organizational culture, participants were asked to report on workplace priorities and views following the dimensions of the competing values framework.

\subsubsection{Sampling Procedures}

After the university research ethics board granted approval for the study, a trial run of the questionnaire was administered to a small sample of staff members (Note 1) to pilot test the questions. Upon completion of the 
pilot test, any necessary questionnaire changes were made, and then recruitment and data collection began. Using Simple Survey software (http://www.simplesurvey.com), the information letter/consent form and survey were uploaded online and a URL was created for participants to access the survey.

A list of 466 university employees was obtained from the campus phone and email directory. In the recruitment email, the purpose of the study was explained and a link to the online survey, as well as the consent form, were included. Before the onset of the survey, participants were asked to read the information letter, which explained the purpose of the study, assured confidentiality of personal information, and offered participants the option to withdraw from the survey at any time if they wished. At this point, participants were asked whether or not they agreed to participate in the survey. If participants selected the box labeled "yes" they were able to begin the survey. When completed, a thank-you message appeared on the screen and participants were instructed to exit the survey. Two reminder emails were sent out during the three-month duration of the study to encourage participation. As an incentive, participants were informed at the onset of the survey that, once data collection was complete, the researchers would draw two names to receive $\$ 10$ gift cards to the local coffee shop/university pub. With 227 responses to the online survey, this study had a near 50\% response rate.

\section{Analysis and Results}

\subsection{Data Analysis}

Data from completed questionnaires were downloaded into an excel spreadsheet, then imported and analyzed in IBM SPSS Statistics 23. Principal components extraction with varimax rotation was performed on 16 items from the survey (excluding demographic items) as a manipulation check to estimate the number of components survey questions loaded onto, to ensure the items were related. Components were internally consistent and well defined by the variables and all variables loaded onto a component. These findings were not discussed further as they did not relate to the research questions.

In addition to intercorrelations between stress, enjoyment of work, productivity and demographic variables, two types of statistical analyses were conducted to answer the research questions: (1) descriptive statistics to determine the dominant type of organizational culture at the studied university; and (2) multivariate analyses of variance (MANOVA) and post-hoc tests to examine any effects of organizational culture on employee stress, enjoyment of work and self-perceived productivity. The first analysis answers research question 1; the second analysis answers research questions 2-4. Males and females were not statistically different from each other on any of the interested variables; therefore, they were analyzed together.

Also included in the survey was an open-ended question (improvements the university could make to organizational culture to increase employee productivity). A thematic analysis was conducted on the responses of this question. This question was not analyzed in SPSS, but was analyzed with an inductive phenomenological approach (Bazeley, 2009; Braun \& Clarke, 2006). This process allows for openness to responses and for various perspectives to emerge from the data, a procedure especially useful in cultural research (Bazeley, 2009; Creswell, 2007).

\subsection{Key Findings}

\subsubsection{Research Question 1}

Descriptive statistics were conducted to determine the dominant type of organizational culture at the studied university. For each dimension of organizational culture, frequencies are provided in Table 2. The dominant type of organizational culture, as identified by employees, was the hierarchy culture. Over half of the employees $(55 \%)$ identified a work environment characteristic of the hierarchy culture, emphasizing structure and efficiency. The second most commonly identified type of culture was the adhocracy culture, with $19 \%$ of the employees identifying their workplace advocating innovation and creativity. The third most common type of culture identified was the market culture, with $17 \%$ of the employees classifying their work environment as placing competition and achievement first. The least commonly identified type of organizational culture was the clan culture, with only $9 \%$ of the employees identifying their work environment as strongly valuing employee well-being, cooperation and teamwork. Interestingly, when employees were asked to report their level of satisfaction with the organizational culture at the university, $34 \%$ reported they were rarely or not at all satisfied ( $45 \%$ somewhat satisfied; $22 \%$ often or always satisfied). 
Table 2. Descriptive statistics for employee stress, enjoyment of work and productivity by the type of organizational culture

\begin{tabular}{ccccc}
\hline Variable & & Stress & Enjoyment & Productivity \\
\hline Culture type $(\mathrm{n}=172)$ & & & & \\
Clan & Mean & 11.50 & 15.75 & 7.13 \\
$\mathrm{~N}=16(9.1 \%)$ & $S D$ & 2.83 & 1.88 & 1.50 \\
Hierarchy & Mean & 14.49 & 14.53 & 6.72 \\
$\mathrm{~N}=93(54.9 \%)$ & $S D$ & 3.29 & 2.66 & 1.53 \\
Adhocracy & Mean & 14.15 & 14.67 & 6.70 \\
$\mathrm{~N}=33(18.9 \%)$ & $S D$ & 3.02 & 2.27 & 1.57 \\
Market & Mean & 16.37 & 12.83 & 5.77 \\
$\mathrm{~N}=30(17.1 \%)$ & $S D$ & 3.18 & 2.26 & 1.79 \\
\hline
\end{tabular}

Note. Stress score range is 5-25, with low numbers representing low stress and high numbers representing high stress. Enjoyment score range is 3-20, with low numbers representing low enjoyment and high numbers representing high enjoyment. Productivity score range is $2-10$, with low numbers representing low productivity and high numbers representing high productivity. $\mathrm{N}=172$ participants who were included in the MANOVA statistical model. Other cases were removed due to missing or incomplete data.

\subsubsection{Research Questions 2-4}

To address research questions 2-4, a multivariate analysis of variance (MANOVA) was performed. The composite variable scores for (1) stress, (2) enjoyment of work and (3) self-perceived productivity were the dependent variables; organizational culture was the independent variable.

Prior to conducting the MANOVA, the three dependent variables were examined to see how they fit with MANOVA assumptions (Tabachnick \& Fidell, 2013). The assumptions were satisfied and Mahalanobis tests did not reveal any multivariate outliers $(p<.001)$, nor were there any univariate outliers. Missing data were excluded from analyses; no other corrections were made as there was a low percentage of missing data. Employee stress, enjoyment of work and productivity were analyzed by a one-way MANOVA with four independent groups: market culture, clan culture, hierarchy culture and adhocracy culture. Of the full sample, data from 172 participants were included in the statistical model.

Using Pillai's Trace criterion, it appeared that employee stress, enjoyment of work and productivity were significantly affected by organizational culture, denoted by a significant multivariate main effect: $F(9,504)=$ $3.18, p=.001, \eta^{2}=.05$. To investigate the influence organizational culture exerts on each dependent variable and examine the significance of main effects, a series of three univariate tests (ANOVAs) were conducted. A Bonferroni-corrected alpha level of $.02(.05 / 3)$ was used to take into account the tendency of type 1 errors from conducting multiple tests. Significant main effects for stress, enjoyment and productivity were followed by post hoc tests using Tukey's honestly significant difference (HSD) tests.

The univariate main effect of organizational culture was significant for stress, $F(3,168)=8.31, p<.001, \eta^{2}=.13$, enjoyment of work, $F(3,168)=5.87, p=.001, \eta^{2}=.10$, and productivity, $F(3,168)=3.56, p=.016, \eta^{2}=.06$. The ANOVA for stress showed a large effect size, representing a strong relationship with organizational culture, while enjoyment and productivity had moderate effect sizes.

Post-hoc tests for stress revealed five significant mean differences between types of organizational culture. Employees working in a clan culture had significantly lower stress scores than employees working in a market culture, $M_{\text {Difference }}=4.87, p<.001,95 \%$ CI $[2.31,7.42]$, as did employees in a clan culture compared to employees in a hierarchy culture, $M_{\text {Difference }}=2.99, p=.004,95 \%$ CI $[.76,5.23]$, employees in a clan culture compared to employees in an adhocracy culture, $M_{\text {Difference }}=2.65, p=.034,95 \%$ CI $[.14,5.17]$, employees in an adhocracy culture compared to employees in a market culture, $M_{\text {Difference }}=2.22, p=.032,95 \%$ CI $[.13,4.30]$, and employees in a hierarchy culture compared to employees in a market culture, $M_{\text {Difference }}=1.87, p=.029,95 \% \mathrm{CI}$ $[.14,3.61]$. Employees who identified working in a clan culture had the lowest levels of work-related stress, followed by employees in the adhocracy and hierarchy cultures (no significant difference), then employees in a market culture (which had the highest levels of employee work-related stress). Post-hoc test results are shown in Figure 1. 


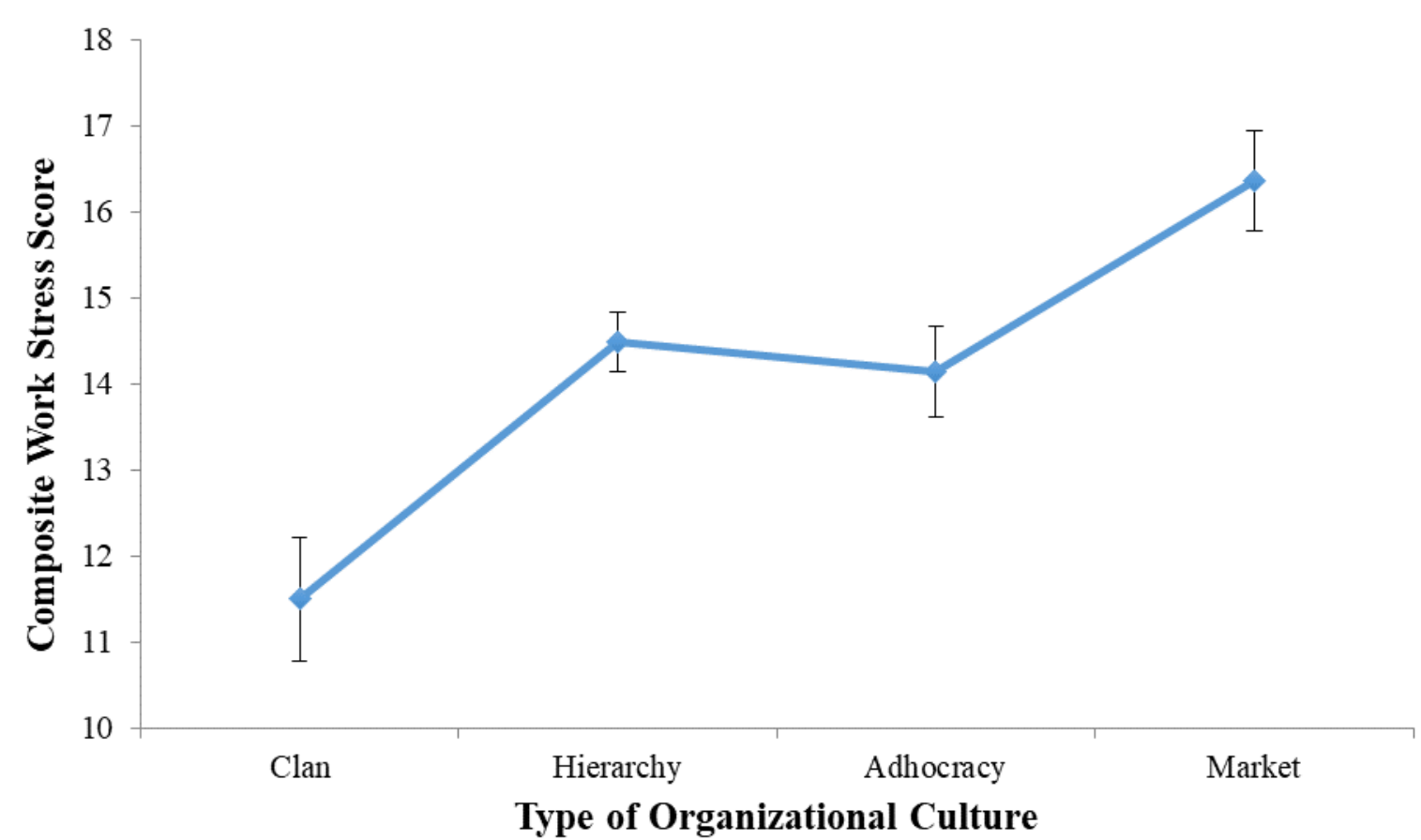

Figure 1. Work-related stress scores broken down by organizational culture. $\mathrm{N}=172$

Post-hoc tests for enjoyment of work revealed three significant mean differences between types of organizational culture. Employees working in a clan culture had significantly higher levels of enjoyment of work than employees working in a market culture, $M_{\text {Difference }}=2.92, p=.001,95 \%$ CI $[.94,4.89]$, as did employees working in an adhocracy culture compared to employees working in a market culture, $M_{\text {Difference }}=1.83, p=.019,95 \% \mathrm{CI}$ $[.22,3.44]$, and employees working in a hierarchy culture compared to employees working in a market culture, $M_{\text {Difference }}=1.69, p=.007,95 \%$ CI $[.35,3.03]$. Employees in the clan culture had the highest enjoyment of work, followed by employees in the adhocracy and hierarchy cultures, with employees in the market culture having the lowest enjoyment of work. Working in a clan, hierarchy, or adhocracy culture was associated with having significantly greater enjoyment of work than working in a market culture. Post-hoc test results are shown in Figure 2 . 


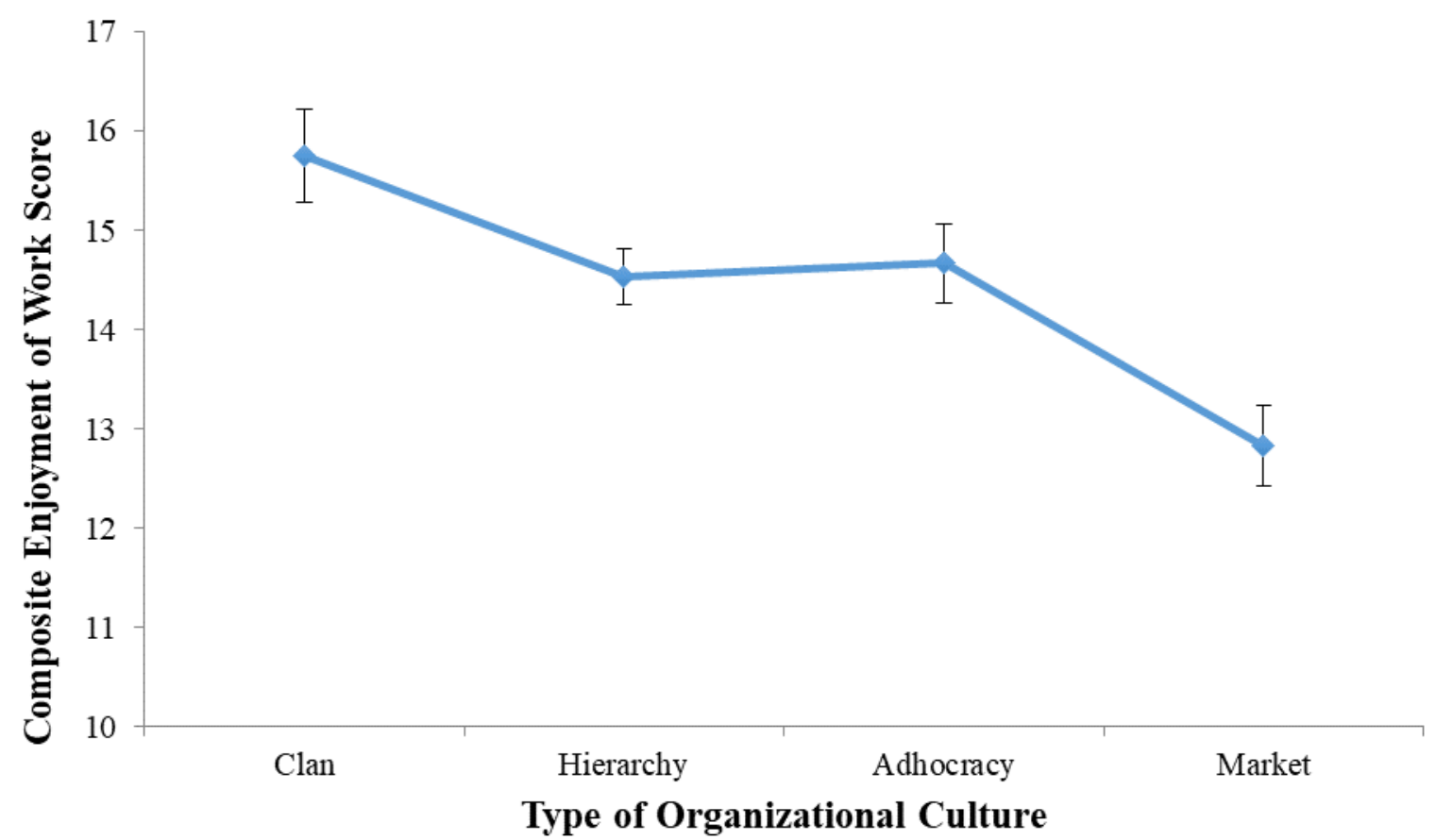

Figure 2. Enjoyment of work scores broken down by organizational culture. $\mathrm{N}=172$

Post-hoc tests for productivity revealed two significant mean differences among types of organizational culture. Employees who identified working in a clan culture had significantly higher self-perceived productivity than employees working in a market culture, $M_{\text {Difference }}=1.36, p=.032,95 \%$ CI $[.08,2.63]$, as did employees working in a hierarchy culture compared to employees working in a market culture, $M_{\text {Difference }}=.95, p=.024,95 \% \mathrm{CI}[.09$, 1.82]. Employees working in a clan culture had the highest self-rated productivity, followed by those in the hierarchy and adhocracy cultures, then employees in the market culture. Employees in the clan and hierarchy cultures had significantly greater self-perceived productivity than employees in the market culture. Post-hoc test results are shown in Figure 3. 


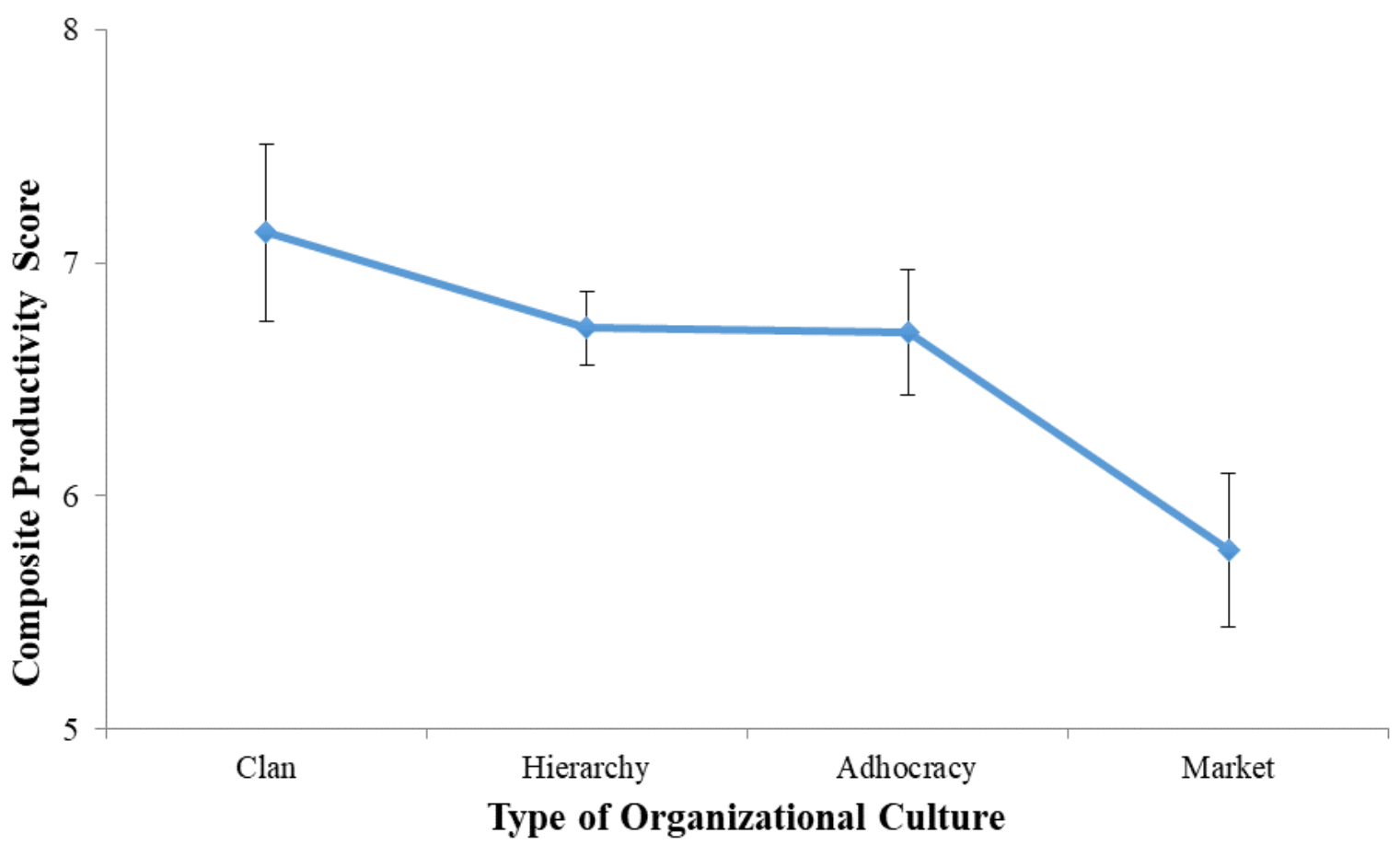

Figure 3. Self-perceived productivity scores broken down by organizational culture. $\mathrm{N}=172$

\subsection{Ancillary Analyses}

\subsubsection{Correlations Among Variables}

Intercorrelations among variables were conducted for the dependent variables of stress, enjoyment of work and productivity, and for demographic variables. The findings are: (1) stress level was strongly, negatively correlated with enjoyment of work; (2) stress level was moderately, negatively correlated with productivity; and (3) enjoyment of work was moderately, positively correlated with productivity. All three relationships were significant $(p<.01$ alpha level two-tailed). These findings support the use of a MANOVA to analyze data. Pearson correlations for the nine variables are displayed in Table 3.

Table 3. Intercorrelations between stress, enjoyment, productivity and demographic variables.

\begin{tabular}{|c|c|c|c|c|c|c|c|c|c|}
\hline & 1. & 2. & 3. & 4. & 5. & 6. & 7. & 8. & 9. \\
\hline 1. Stress & - & & & & & & & & \\
\hline 2. Enjoyment & $-.681^{* *}$ & - & & & & & & & \\
\hline 3. Productivity & $-.477 * *$ & $.526^{* *}$ & - & & & & & & \\
\hline 4. Salary satisfaction & $-.294 * *$ & $.268 * *$ & $.856^{* *}$ & - & & & & & \\
\hline 5. Age & $.214 * *$ & -.073 & -.041 & -.071 & - & & & & \\
\hline 6. Years at university & $.214 * *$ & $-.195 * *$ & -.048 & -.009 & $.433 * *$ & - & & & \\
\hline 7. Health & $-.333 *$ & $.189^{* *}$ & $.222 * *$ & $.205 * *$ & -.081 & $-.174^{*}$ & - & & \\
\hline 8. Salary level & $.174 *$ & -.107 & -.139 & -.088 & $.194 *$ & $.261 * *$ & -.074 & - & \\
\hline 9. Gender & -.030 & -.002 & .115 & .053 & -.013 & .045 & -.016 & $-.235^{* *}$ & - \\
\hline
\end{tabular}

Note. $* * p<.01 ; * p<.05$

3.3.2 Qualitative Analysis

Responses to an open-ended question asking, "What changes to the organizational culture of [university name] would increase your productivity?" were analyzed. This analysis provided a multitude of answers and rich descriptions of the way employees at the university believe organizational culture influences their productivity at 
work, and ways in which increased productivity could be promoted and achieved. During this analysis process, thematic units were recognized and then assigned to categories through the inductive process described by Braun and Clarke (2006). A phenomenological approach was used to guide analysis, with detailed coding leading to the creation of several specific categories (Bazeley, 2009). A total of three themes emerged from coding. Raw data were checked several times to ensure the three categories were the most prevalent and an appropriate summary of the thematic analysis.

The three general themes that emerged from analysis were: (1) The desire for a work structure that allows job flexibility, (2) A want for increased cooperation and care for university employees, and (3) The desire for the university to share a common goal.

The desire for flexibility was illustrated by comments such as "...having a more flexible work schedule..." would increase productivity and "recognizing the need to balance work/home life and better recognition for a job well done" would make work more enjoyable. Employees voiced opinions that their "...department doesn't offer flex days. This may help with increasing productivity and overall morale" at the university. Additionally, there were comments that employees wished there were a "...more clear structure..." and that they were "...given more flexibility" in work positions that would allow for "...job advancement..." and the "...ability to grow" at the university. Such comments illustrate that a shift in job structure, which allows for job flexibility, is desired.

The majority of employees identified that a "shift in culture to value and respect all staff, students and faculty while encouraging cooperation and collaboration to create innovative solutions" could greatly improve employee productivity. Comments that the university should foster "open communication at all levels," as well as that " [people] need to realize that we are a TEAM..." and that the university should create "... a more positive morale for employees/staff..." frequently emerged. It is apparent that employees feel they work in a "bureaucratic" or "autocratic" environment, which suppresses employee creativity and freedom at work. Interestingly, there were comments that "collaboration is a word used often, however it is not understood," which suggests there may be a disconnection between desires and reality at the institution. It was suggested that "increased team work..." and "...more departmental co-operation" could stem from a "more collegial environment... [and] positive leadership...", which could lead to the "appreciation" that some employees seem to feel is lacking at the university. Overall, it can be summarized that the university "...need[s] more of a team environment where everybody is wanting to contribute to a solution rather than continually setting up roadblocks."

A final theme that emerged had to do with the desire for the university to have "...alignment of a common vision" to "provide common direction and goals that everybody follows..." at the institution. This comment re-emerged in similar forms such as "a clear direction on what our university's mission, goals, and direction will be" and "we need a clear strategic vision with measureable goals," which illustrate the desire for salient goals. As stated by one employee, "it would be great to have a vision the entire university is working towards...", which could increase staff collaboration as well as productivity.

In summary, while some employees could not identify areas to be improved upon, or they felt the university was "\#1 in view of organizational/professional culture," many other employees felt that there was room for improvement through "appreciation...communication...inclusion and consultation," and having "...true collaboration and innovation, rather than just 'talking about it'."

\section{Discussion}

The four objectives of this study were to: (1) determine the dominant type of organizational culture at the studied university, and explore whether or not, and how, organizational culture influences (2) employee work-related stress, (3) enjoyment of work, and (4) self-perceived productivity. The most interesting findings will be discussed below.

\subsection{Organizational Culture at A Northern Canadian University Setting}

With respect to the dominant type of organizational culture at the studied university, frequency analyses produced the following findings: First, all types of organizational culture (clan, hierarchy, adhocracy and market) were identified in varying degrees. This finding is in accordance with existing studies, which have found that no institution is characterized fully by one type of culture (Cameron \& Freeman, 1985). Second, the hierarchy culture was the dominant type of organizational culture at the university, with the clan culture being the least prevalent. This shows cultural congruence at the institution, with one type of organizational culture dominating many sectors of the organization (Cameron \& Quinn, 2005). It is possible the system structure and bureaucratic nature of universities create a backbone for a hierarchy culture to be adopted. While originally referred to as a professional-bureaucracy culture, the characteristics Mintzberg found in university settings fit that of the 
hierarchy culture. The finding that universities (such as McGill University) resemble characteristics of a hierarchy culture (Mintzberg, 1979; Mintzberg, 1993) overlaps with our findings. Our results support another study which found that Canadian universities tend to be predominantly bureaucratic and structure-driven, which seems to fit with the hierarchy culture (Burnett \& Huisman, 2009). This appears to be reasonable, as organizational literature claims that similar organizations tend to exhibit similar kinds of culture (Chatman \& Jehn, 1994). Interestingly, a limited body of research has identified that universities tend to embody a clan culture rather than a hierarchy culture (Berrio, 2003), which contrasts what was found in the present study. Indeed, Berrio (2003) has found that in one American university, the clan culture was dominant and preferred by employees, with the hierarchy culture being the second most commonly identified. One may argue that Canadian and American institutions have different values and priorities, hence the differences in their cultures.

According to Bartell (2003), universities share a unique set of characteristics and a specific culture type compared to other organizations, which is likely related to the highly-organized management systems. This could explain why universities tend to identify clan or hierarchy cultures, and why large institutions commonly show hierarchy characteristics (Berrio, 2003; Cameron \& Freeman, 2005). The unique set of characteristics that universities tend to share (Bartell, 2003) may override any unique attributes of specific areas of employment, thus exhibiting a hierarchy culture. These findings point to a context-specific view of organizational culture in university settings, suggesting that the hierarchy and clan cultures may be more dominant than the adhocracy and market cultures at universities.

\subsection{Organizational Culture and Employee Stress, Enjoyment of Work and Productivity}

We found that organizational culture is significantly related to employee stress, enjoyment of work and self-perceived productivity. A main effect was found for organizational culture on all three dependent variables, with significant post-hoc tests. The moderate-to-large effect sizes support the findings. As indicated by effect sizes, stress had the greatest relationship with organizational culture, followed by enjoyment of work, then productivity. When individuals categorized themselves as working in a clan or hierarchy culture they had significantly lower levels of stress, higher levels of productivity and higher levels of enjoyment of work than employees who identified working in a market culture. Employees in the clan culture had the lowest stress, and highest enjoyment and self-perceived productivity. Employees who worked in an adhocracy culture had higher stress, lower enjoyment and lower productivity than employees in a clan culture. However, they did show significantly lower levels of stress and higher enjoyment of work than employees working in a market culture. Overall, the clan culture had the most positive outcomes, followed by the adhocracy and hierarchy cultures, and then the market culture. These results are consistent with a study reporting that the clan and hierarchy cultures appear to be the most positive environments to work in (OCAI Online, 2012).

Regarding differences in stress levels, it can be posited that the collaborative, supportive and loyal characteristics of the clan culture versus the competitive and harsh characteristics of the market culture contributed to such differences. Studies conducted in Australia and the United Kingdom among university staff also identified poor management practices, insufficient reward and recognition, poor relationships, job insecurity, and work overload, as major sources of stress (Gillespie, Walsh, Winefield, Dua, \& Stough, 2001; Tytherleigh, Webb, Cooper, \& Ricketts, 2005). The importance market cultures place on job advancement, and the amount of "whip-cracking", believed to occur in such organizations may explain why higher stress levels were found. Moreover, market cultures tend to have the highest levels of conflict, resulting in poor relationships, known to increase job stress. Finally, while rewards are offered in market cultures, it is only for high achievement, meaning that many employees may go without recognition, contributing to stress (Cameron \& Quinn, 2005). Conversely, variables such as support from management and co-workers, group morale, flexible work conditions and recognition have been reported to help staff reduce and cope with job stress (Gillespie et al., 2001). These variables are characteristics of the clan culture (Cameron \& Quinn, 2005), which are in line with our finding that employees in the clan culture had the lowest levels of reported stress. Studies have shown that clan cultures have the highest employee health, followed by the adhocracy culture, then the hierarchy and market cultures (Cameron \& Freeman, 1985). Notably, clan cultures are known to have a low power distance. Kheirandish et al (2016) found that a greater power distance can be linked with greater stress and thus, eventual burnout. The results of our study have provided strong support for these findings that organizational culture is related to employee stress level, an indicator of physical and psycological health.

We found that employees in the clan culture had the highest enjoyment of work, followed by the adhocracy culture, then the hierarchy culture, and finally the market culture. Our findings seem to be consistent with two college studies, which found that the clan culture strongly relates to satisfaction (Cameron \& Quinn, 2005, Cameron \& Freeman, 1985). It is believed that the supportive environment and high group identity of the clan 
culture can explain such findings (Cameron \& Freeman, 1985; Cameron \& Quinn, 2005). Moreover, another study identified that job satisfaction is positively associated with the clan and adhocracy cultures, and negatively associated with the hierarchy and market cultures (Lund, 2003). Past research also suggests that cultures which emphasize teamwork and value human interactions are strongly related to high job satisfaction (San Park \& Hyun Kim, 2009). Researchers have aslo reported that clan cultures have low job turnover (Lok \& Crawford, 2004; Ozturk, Hancer, \& Wang, 2014). When employees are happy, they tend to stay. Conversely, the high turnover rate of employees in market cultures may well be a result of low enjoyment of work, such as that found in the present study and in other studies (Banaszak-Holl, Castle, Lin, Shrivastwa, \& Spreitzer, 2015). It is possible that the adhocracy culture also leads to high employee enjoyment of work because of the creative, flexible and innovative environment, while the rule-driven environment of the hierarchy culture, and competitive and stressful aspects of the market culture are too rigid to foster enjoyment (Naranjo-Valencia, Jiménez-Jiménez, \& Sanz-Valle, 2011).

Finally, we found significant differences in productivity between the clan and market cultures, and the hierarchy and market cultures. Other studies have also found differences in workplace effectiveness across types of organizational culture (Mahdiyeh et al., 2016). Our study revealed higher self-reported productivity scores for employees who identified the clan culture compared to any other culture type. However, our finding that the hierarchy culture is second highest in productivity contradicts existing research, which shows that the adhocracy culture ranks after the clan culture (Cameron \& Freeman, 1985). Although initial perceptions may lead one to believe the market culture would have the highest productivity, the opposing finding can be explained in a few ways. First, as productivity was self-perceived, it is possible that employees in the clan culture simply perceived themselves to be more productive. It is also possible that the high goals and expectations of the market culture lead employees to feel they are never fully productive, whereas the employee-oriented environment of the clan culture makes employees believe they are productive. Another possible explanation is that the high stress from the market culture hinders employee productivity. Research has identified a link between job stress and productivity, with employee productivity being adversely affected by levels of job stress (Naqvi, Khan, Kant, \& Khan, 2013).

Overall, our findings support existing research, which has shown that employees in clan cultures have the lowest job stress, highest enjoyment of work and highest productivity, and that employees in market cultures show the opposite.

\subsection{Relationships among Stress, Enjoyment, Productivity and Demographic Variables}

We found significant correlations for stress, enjoyment of work and self-perceived productivity. Stress was positively correlated with age, years worked at the university and salary level, and was negatively correlated with salary satisfaction and health status. Enjoyment was positively correlated with salary satisfaction and health status, and was negatively correlated with years worked at the university. Productivity was positively correlated with health status and salary satisfaction.

It can be argued that employees earning a higher annual salary are more stressed due to higher work demands. Moreover, working at the university for a long period of time may mean that one is more likely to hold a high-stress position, such as management. The finding that health status is negatively related to stress seems reasonable, as life stress is known to presage poor health (McEwen \& Gianaros, 2010). Interestingly, it was found that salary satisfaction was negatively related to stress. Although salary level was positively related to stress, it seems that one's satisfaction with their salary may act as a buffer to stress, which aligns with research that reports pay satisfaction and pay fairness are not synonymous (Judge, Piccolo, Podsakoff, Shaw, \& Rich, 2010; Scarpello \& Carraher, 2008), and that job stress is related to satisfaction with work reward packages (Lu, While, \& Barriball, 2005).

Correlation analyses of enjoyment show that employees who enjoyed work were more likely to be of good health and satisfied with their salaries. Interestingly, there was an inverse function where employees working at the university for four years or less, and twenty years or more, reported the highest enjoyment. Our findings support existing research reporting that enjoyment of work was strongly correlated with health (Faragher, Cass, \& Cooper, 2005) and pay satisfaction (Sharma \& Bajpai, 2011).

Our findings on correlates of productivity are in agreement with those found in the literature. Past research identifies a strong relationship between productivity and employee health status, wherein poor health is linked with productivity loss (Van den Heuvel, Geuskens, Hooftman, Koppes, \& Van den Bossche, 2010). Regarding salary satisfaction, it is logical that if an individual is not satisfied with their salary they will be less motivated to work at a high level of performance. 


\subsection{Qualitative Analysis}

Employees felt their workplace productivity could be improved if teamwork, collaboration and coordination were enhanced at the university. Employees most commonly voiced desires fitting with aspects of the clan culture, yet this culture was the least commonly identified in the survey. It is apparent that employees want increased flexibility, cooperation and communication, as well as shared goals and values, which are known to represent the clan culture. However, flexibility also shows overlap with the adhocracy culture. Moreover, the characteristics employees identified as being detrimental to productivity, such as autocratic environments, did not fit with the clan culture but may be characteristic of the market culture. This suggests that the majority of the employees do not enjoy working in other culture types as much as they do in the clan culture. There was little discussion on aspects of the hierarchy or adhocracy cultures, indicating these cultures may represent a middle ground in terms of employee preferences for productivity.

Taken together, these findings could be used by the studied university (and other organizations) to aid in organizational change efforts and the development of procedures to increase the employee workplace experience (Rothwell, Stavros, Sullivan, \& Sullivan, 2009). Although the hierarchy culture might be necessary for the smooth functioning of universities, strategic planning paired with educational and team-building activities could be used to increase flexibility, create a common vision and improve cooperation at the institution. This may help incorporate aspects of the clan culture into the university's workplace as employees appear to so desire. When it comes to shifting organizational culture dynamics, it is often helpful to begin with a needs assessment, along with dialogue between management and employees on what outputs they would like to see from change efforts (Aguinis \& Kraiger, 2009), which for the studied university were flexibility, shared goals and cooperation. Following these steps, a schedule of educational sessions and activities could be set up to address common goal setting, problem-solving techniques, human relations, and clarification of roles and policies (Aguinis \& Kraiger, 2009; Klein et al., 2009). This could be accompanied by supervisory training to create a dynamic organizational culture to both optimize organizational procedures and productivity, while also maximizing the employee experience through team building.

\subsection{Implications}

Overall, the results of our study clearly demonstrate that organizational culture influences employee stress, enjoyment of work and self-perceived productivity. Our study also provides valuable information on the type(s) of organizational culture at a Canadian university, which is predominantly the hierarchy culture. The intricate relationship(s) between organizational culture and the employee workplace experience found in the present study have practical implications for organizational leaders and employees. Study findings may act as a caution for organizational leaders to be cognizant of how they manage an organization and the potential problems of building a heavily market-oriented environment. Indeed, this study highlights the importance of organizational culture and the potential economic benefits of creating a cooperative, welcoming and flexible work environment for employees. That is, reduced stress/sick leave, increased productivity, increased enjoyment of work and employee retention. By gaining a deeper understanding of the interconnection between organizational culture, employee stress, enjoyment of work and productivity, organizational leaders may be better equipped to facilitate prosperous organizations.

\subsection{Limitations and Future Research}

The present study has certain limitations which should be considered. The first limitation is the self-report nature of the measures, which may or may not be accurate. Second, we had unequal sample sizes in our MANOVA analysis. Although this can pose the risk of decreased interpretation (Tabachnick \& Fidell, 2013), MANOVA analyses are quite robust to unequal sample sizes if other assumptions are met, and if the smallest group is four-to-five times larger than the number of variables included in analysis (Poulsen \& French, 2008).

Future studies could expand upon our study by doing the following. First, our study was conducted in a Canadian university setting, among English-speaking employees. Future studies could investigate whether such results are seen among other Canadian organizations, in other countries, and even among university faculty as opposed to university staff. This could improve the generalizability of results. Second, it would be informative to examine the role other variables (e.g., area of employment) play in the relationship between culture and the dependent variables, as these factors may interact with organizational culture to influence employee stress, enjoyment of work and productivity. Finally, a person-organization fit perspective could increase the value of present research and expand on knowledge in the field. 


\section{Conclusion}

In summary, the present study advances existing knowledge in two ways. First, by exploring organizational culture in a Canadian institution, new insight is gained into how organizational culture influences employee stress, enjoyment of work and self-perceived productivity. Second, the finding that the hierarchy culture was dominant in the university is worthy of attention since the clan culture was identified as having the lowest stress, and highest enjoyment of work and self-perceived productivity. In order to increase employee happiness and organizational efficiency, management should strategically shape its culture into a more clan-oriented culture.

\section{Acknowledgments}

The authors would like to thank Drs. Paul Siakaluk and Michel Bouchard for their consultation and assistance with this research.

\section{References}

Aguinis, H. \& Kraiger, K. (2009). Benefits of training and development for individuals and teams, organizations, and society. The Annual Review of Psychology, 60, 451-474. https://doi.org/10.1146/annurev.psych.60.110707.163505

Banaszak-Holl, J., Castle, N. G., Lin, M. K., Shrivastwa, N. \& Spreitzer, G. (2015). The role of organizational culture in retaining nursing workforce. The Gerontologist, 55(3), 462-471. https://doi.org/10.1093/geront/gnt129

Bartell, M.B. (2003). Internationalization of Universities: A university culture based framework. Higher Education, 45(1), 43-70. https://doi.org/10.1023/a:1021225514599

Baumeister, R. F., Bratslavsky, E., Muraven, M. \& Tice, D. M. (1998). Ego depletion: is the active self a limited resource?. Journal of Personality and Social Psychology, 74(5), 1252. https://doi.org/10.1037/0022-3514.74.5.1252

Bazeley, P. (2009). Analysing qualitative data: More than 'identifying themes'. Malaysian Journal of Qualitative Research, 2(2), 6-22.

Berrio, A. A. (2003). An organizational culture assessment using the competing values framework: A profile of Ohio State University Extension. Age, 2(699), 1-052.

Braun, V. \& Clarke, V. (2006). Using thematic analysis in psychology. Qualitative Research in Psychology, 3(2), 77-101. https://doi.org/10.1191/1478088706qp063oa

Brown, S. P. \& Leigh, T. W. (1996). A new look at psychological climate and its relationship to job involvement, effort and performance. Journal of Applied Psychology, 81(4), 358-368. https://doi.org/10.1037/0021-9010.81.4.358

Burnett, S-A. \& Huisman, J. (2009). Universities' responses to globalization: The influence of organizational culture. Journal of Studies in International Education, 1-25. https://doi.org/10.1177\%2F1028315309350717

Cameron, K. S. \& Freeman, S. J. (1985). Cultural congruence, strength, and type: Relationships to effectiveness. School of Business Administration, University of Michigan.

Cameron, K. S. \& Quinn, R. E. (2005). Diagnosing and changing organizational culture: Based on the competing values framework. John Wiley \& Sons.

Cawsey, T. (1973). The interaction of motivation and environment in the prediction of performance potential and satisfaction in the life insurance industry in Canada. Paper presented at 16th Annual Midwest Academy of Management Meeting, Chicago: Illinois.

Chatman, J. A. \& Jehn, K. A. (1994). Assessing the relationship between industry characteristics and organizational culture: How different can you be? Academy of Management Journal, 37(2), 522-553. https://doi.org/10.2307/256699

Clements-Croome, D. (Ed.). (2006). Creating the productive workplace. Taylor \& Francis.

Conger, J. \& Kanungo, R. (1988). Charismatic Leadership: The elusive factor in organizational effectiveness. San Francisco, CA: Jossey Bass.

Creswell, J. W. (2007). Qualitative enquiry and research design: Choosing among five approaches. Thousand Oaks, CA: Sage.

Denison, D. R. (1996). What is the difference between organizational culture and organizational climate? A 
native's point of view on a decade of paradigm wars. The Academy of Management Review, 21(3), 619-654. https://doi.org/10.5465/amr.1996.9702100310

Denison, D. R. \& Spreitzer, G. M. (1991). Organizational culture and organizational development: A competing values approach. Research in Organizational Change and Development, 5, 1-21.

Dunnette, M. (1973). Performance equals ability and what? (Unpublished paper, University of Minnesota).

Earle, H.A. (2003). Building a workplace of choice: using the work environment to attract and retain top talent. Journal of Facilities Management, 2(3), 244-257. https://doi.org/10.1108/14725960410808230

Faragher, E. B., Cass, M. \& Cooper, C. L. (2005). The relationship between job satisfaction and health: a meta-analysis. Occupational and Environmental Medicine, 62(2), 105-112. https://doi.org/10.1136/oem.2002.006734

Frederickson, N. (1966). Some effects of organizational climates on administrative performance. Research memorandum, RM-66-21, Educational Testing Service.

Friedlander, F. \& Greenberg, S. (1971). Effect of job attitudes, training, and organization climate on performance of the hard-core unemployed. Journal of Applied Psychology, 55(4), 287-295. https://doi.org/10.1037/h0031532

Friedlander, F. \& Margulies, N. (1969). Multiple impacts of organizational climate and individual value systems $\begin{array}{lllll}\text { upon job satisfaction. Personnel } & \text { Psychology, } & \text { 22, }\end{array}$ https://doi.org/10.1111/j.1744-6570.1969.tb02300.x

Ganster, D. C., Schaubroeck, J., Sime, W. E. \& Mayes, B. T. (1990). Unhealthy leader dispositions, work group strain and performance. Best papers. Proceedings of the Academy of Management, 191-195. https://doi.org/10.5465/ambpp.1990.4978694

Goffee, R. \& Jones, G. (1996). "What holds the modern company together?" Harvard Business Review, 74(6), 133-49.

Gillespie, N. A., Walsh, M. H. W. A., Winefield, A. H., Dua, J. \& Stough, C. (2001). Occupational stress in universities: staff perceptions of the causes, consequences and moderators of stress. Work \& Stress, 15(1), 53-72. https://doi.org/10.1080/02678370117944

Hackman, J. R. \& Oldham, G. R. (1975). Development of the Job Diagnostic Survey. Journal of Applied Psychology, 60, 159-170. https://doi.org/10.1037/h0076546

Hammer, T. H., Bayazit, M., Saksvik, P. O., Nytro, K. \& Torvatn, H. (2004). Expanding the psychosocial work environment: workplace norms and work-family conflict as correlates of stress and health. Journal of Occupational Health Psychology, 9(1), 83-97. https://doi.org/10.1037/1076-8998.9.1.83

Hellriegel, D. \& Slocum, J. W. (1974). Organizational climate: measures, research and contingencies. The Academy of Management Journal, 17(2), 255-280. https://doi.org/10.5465/254979

Judge, T. A., Piccolo, R. F., Podsakoff, N. P., Shaw, J. C. \& Rich, B. L. (2010). The relationship between pay and job satisfaction: A meta-analysis of the literature. Journal of Vocational Behavior, 77(2), 157-167. https://doi.org/10.1016/j.jvb.2010.04.002

Kaczka, E. \& Kirk, R. (1968). Managerial climate, work groups, and organizational performance. Administrative Science Quarterly, 12, 252-271. https://doi.org/10.2307/2391551

Kahn, W. A. (1990). Psychological conditions of personal engagement and disengagement at work. Academy of Management Journal, 33(4), 692-724. https://doi.org/10.5465/256287

Kane-Urrabanzo, C (2006). Management's role in shaping organizational culture. Journal of Nursing Management, 14, 188-194. https://doi.org/10.1111/j.1365-2934.2006.00590.x

Kheirandish, M., Farahani, A. \& Nikkhoo, B. (2016). The impact of Organizational Culture on employees' Job Burnout. Human Resource Management, 3(10), 1-15.

Klein, C., DiazGranados, D., Salas, E., Le, H., Burke, C.S., Lyons, R. \& Goodwin, G.F. (2009). Does team-building work? Small Group Research, 40(2), 181-222. https://doi.org/10.1177/1046496408328821

Litwin, G. \& Stringer, R. (1968). Motivation and organizational climate. Cambridge, Massachusetts: Harvard University Press.

Lok, P. \& Crawford, J. (2004). The effect of organizational culture and leadership style on job satisfaction and 
organizational commitment. A cross-nation comparison. Journal of Management Development, 23(4), 321-338. https://doi.org/10.1108/02621710410529785

Lu, H., While, A. E. \& Barriball, K. L. (2005). Job satisfaction among nurses: a literature review. International Journal of Nursing Studies, 42(2), 211-227. https://doi.org/10.1016/j.ijnurstu.2004.09.003

Lund, D. B. (2003). Organizational culture and job satisfaction. Journal of Business \& Industrial Marketing, 18(3), 219-236. https://doi.org/10.1108/0885862031047313

Mahdiyeh, M., Nakhaei, H. \& Kebriaei, A. (2016). Impact of Organizational Culture on Productivity: A Study among Employees of Ministry of Youth and Sports, Iran. International Journal of Humanities and Cultural Studies (IJHCS) ISSN 2356-5926, 3(3), 170-177.

Malone, T. (1997). Is empowerment just a fad? Control decision making and IT. Sloan Management Review, 23-35.

Mathieu, J. E. \& Zajac, D. M. (1990). A review and meta- analysis of the antecedents, correlates, and consequences of organizational commitment. Psychological Bulletin, 108, 171-194. https://doi.org/10.1037/0033-2909.108.2.171

Maslach, C. \& Leiter, M.P. (1997). The truth about burnout. How organizations cause personal stress and what to do about it. San Francisco, CA: John Wiley \& Sons.

McEwen, B. S. \& Gianaros, P. J. (2010). Central role of the brain in stress and adaptation: links to socioeconomic status, health, and disease. Annals of the New York Academy of Sciences, 1186(1), $190-222$. https://doi.org/10.1111/j.1749-6632.2009.05331.x

Mintzberg, H. (1979). The structuring of organizations: A synthesis of the research. Englewood Cliffs, N.J: Prentice-Hall.

Mintzberg, H. (1993). Structure in fives: Designing effective organizations. Englewood Cliffs, N.J: Prentice-Hall.

Motowidlo, S. J., Manning, M. R. \& Packard, J. S. (1986). Occupational stress: its causes and consequences for job performance. Journal of Applied Psychology, https://doi.org/10.1037/0021-9010.71.4.618

Naqvi, S. M. H., Khan, M., Kant, A. \& Khan, S. N. (2013). Job Stress and Employees' Productivity: Case of Azad Kashmir Public Health Sector. Interdisciplinary Journal of Contemporary Research in Business, 525-542.

Naranjo-Valencia, J. C., Jiménez-Jiménez, D. \& Sanz-Valle, R. (2011). Innovation or imitation? The role of organizational culture. Management Decision, 49(1), 55-72. https://doi.org/10.1108/00251741111094437

OCAI Online (2012). Report: Organizational culture assessment instrument. Public administration. Retrieved from: www.ocai-online.com

Ozturk, A. B., Hancer, M. \& Wang, Y. C. (2014). Interpersonal trust, organizational culture, and turnover intention in hotels: A cross-level perspective. Tourism Analysis, 19(2), 139-150. https://doi.org/10.3727/108354214X13963557455522

Peterson, M. \& Wilson, J. F. (2002). The culture-work-health model and work stress. American Journal of Health Behaviour, 26(1), 16-24. https://doi.org/10.5993/ajhb.26.1.2

Poulsen, J. \& French, A. (2008). Discriminant function analysis. San Francisco State University: San Francisco, CA.

Rosa, R. R., Colligan, M. J. \& Lewis, P. (1989). Extended workdays: effects of 8-hour and 12-hour rotating shift schedules on performance, subjective alertness, sleep patterns, and psychosocial variables. Work \& Stress, 3(1), 21-32. https://doi.org/10.1080/02678378908256877

Rothwell, W. J., Stavros, J. M., Sullivan, R. L. \& Sullivan, A. (Eds.) (2009). Practicing organization development: A guide for leading change $\left(3^{\text {rd }}\right.$ ed). San Francisco, CA: John Wiley \& Sons, Inc.

San Park, J. \& Hyun Kim, T. (2009). Do types of organizational culture matter in nurse job satisfaction and turnover intention? Leadership in Health Services, 22(1), $20-38$. https://doi.org/10.1108/17511870910928001

Scarpello, V. \& Carraher, S. M. (2008). Are pay satisfaction and pay fairness the same construct? A cross-country examination among the self-employed in Latvia, Germany, the UK, and the USA. Baltic Journal of Management, 3(1), 23-39. https://doi.org/10.1108/17465260810844248 
Schein, E. H. (1984). Coming to a new awareness of organizational culture. Sloan Management Review, 25(2), 3.

Sharma, J. P. \& Bajpai, N. (2011). Salary satisfaction as an antecedent of job satisfaction: Development of a regression model to determine the linearity between salary satisfaction and job satisfaction in a public and a private organization. European Journal of Social Sciences, 18(3), 450-461.

Sheridan, J. E. (1992). Organizational culture and employee retention. The Academy of Management Journal, 35(5), 1036-1056. https://doi.org/10.2307/256539

Sherman, S. G., Leahy, M. J., Del Valle, R., Anderson, C. A., Tansey, T. N. \& Lui, K. (2014). Organizational and cultural factors that promote creative best practices in the public rehabilitation program: Findings from a four-state multiple case study. Journal of Vocational Rehabilitation, 41(2), 115-125. https://doi.org/10.3233/jvr-140710

Soonhee, K. (2002). Participative management and job satisfaction: lessons for management leadership. Public Administration Review, 62(2), 231-241. https://doi.org/10.1111/0033-3352.00173

Sparks, K., Faragher, B., Cooper, C. L. (2001). Well-being and occupational health in the 21st century workplace. Journal of Occupational and Organizational Psychology, 74, 489-509. https://doi.org/10.1348/096317901167497

Spector, P. E. (1986). Perceived control by employees: A meta-analysis of studies concerning autonomy and participation at work. Human Relations, 39, 1005-1016. https://doi.org/10.1177/001872678603901104

Tabachnick, B. G. \& Fidell, L. S. (2013). Using multivariate statistics (6th ed.). Saddle River, NJ: Pearson Education, Inc.

Trice, H. \& Beyer, J. (1993). The Culture of Work Organization. Englewood Cliffs, NJ: Prentice-Hall.

Tytherleigh, M. Y., Webb, C., Cooper, C. L. \& Ricketts, C. (2005). Occupational stress in UK higher education institutions: A comparative study of all staff categories. Higher Education Research \& Development, 24(1), 41-61. https://doi.org/10.1080/0729436052000318569

Vahtera, J., Kivimaki, M. \& Pentti, J. (1997). Effect of organizational downsizing on health of employees. Lancet, 350, 1124-1128. https://doi.org/10.1016/s0140-6736(97)03216-9

Van den Heuvel, S. G., Geuskens, G. A., Hooftman, W. E., Koppes, L. L. \& Van den Bossche, S. N. (2010). Productivity loss at work; health-related and work-related factors. Journal of Occupational Rehabilitation, 20(3), 331-339. https://doi.org/10.1007/s10926-009-9219-7

Williams, L. \& Hazer, J. (1986). Antecedents and consequences of satisfaction and commitment in turnover modes: a re-analysis using latent variables structural equation methods. Journal of Applied Psychology, 71(2), 219-231. https://doi.org/10.1037/0021-9010.71.2.219

\section{Notes}

Note 1. Staff members involved in the trial run were not allowed to also participate in the study.

\section{Copyrights}

Copyright for this article is retained by the author(s), with first publication rights granted to the journal.

This is an open-access article distributed under the terms and conditions of the Creative Commons Attribution license (http://creativecommons.org/licenses/by/4.0/). 